\title{
EFFICACY OF OVERDOSING OF VITAMIN C SUPPEMENTATION ON GROWTH PERFORMANCE, EUROPE PRODUCTION EFFICIENCY FACTOR (EPEF), CARCASS TRAITS AND SOME BLOOD CONSTITUENTS OF JAPANESE QUAIL
}

\author{
Moustafa M. Metwally ${ }^{1}$ and M.A. Metwally ${ }^{2}$ \\ ${ }^{1}$ Agricultural Research Center, Animal Production Research Institute,Giza. Egypt. \\ ${ }^{2}$ Dept. of Poultry Production, Faculty of Agriculture, Assiut University, Assiut, Egypt.
}

(Received 12/7/2021, accepted 9/8/2021)

\section{SUMMARY}

$\mathrm{T}$ The present study was designed to investigate the efficacy of overdose of vitamin C supplementation on growth performance, Europe production efficiency factor (EPEF),carcass traits and some blood constituents of Japanese quail in one way analysis of variance experiment lasted 49 days of age. Two hundred and twenty five of one day old Japanese quail chicks were used. The chicks were distributed into 5 treatments of 3 replicates of 15 birds each. Five levels of vitamin $\mathrm{C}(0,65,130,260$ and $520 \mathrm{mg} / \mathrm{kg}$ diet $)$ were used. The body weight and feed intake were recorded weekly and consequently, body weight gain and feed conversion ratio were calculated. At the end of the experiment, three birds from each group were slaughtered to evaluate carcass parts. Blood serum samples were obtained from chicks at 49 day of age after being centrifuged to measure total protein, cholesterol, glucose, calcium, phosphorus and GPT. The results at 49 days of age, showed that the Japanese quail chicks fed $130 \mathrm{mg}$ of vitamin $\mathrm{C} / \mathrm{kg}$ were significantly $(\mathrm{P}<0.05)$ the best and recorded better values for body weight, body weight gain and feed conversion ratio compared to control and the other treatments.. No significant $(\mathrm{P}>0.05)$ effects due to vitamin $\mathrm{C}$ supplementation were noticed on dressed\%, EPEF, and some blood serum parameters measured, although, there where slight improvements in chicks fed 130 $\mathrm{mg} / \mathrm{kg}$ feed. It was recommended that feed formulation during starter and grower periods, it should be supplemented at least by $130 \mathrm{mg} / \mathrm{kg}$ of vitamin C to achieve good performance and health of Japanese quail.

Keywords: Quail, vitamin C, overdose, performance, carcass and serum.

\section{INTRODUCTION}

The shortage of animal protein intake among the ever increasing human population in the third world countries has long been recognized and remains one of the greatest issues of concern today (Omikhoje et al., 2008). Developing Countries including Egypt are deficient in animal protein security with the per capita consumption put at lower than $10.0 \mathrm{~g} / \mathrm{per}$ day as against the minimum daily intake of $35 \mathrm{~g}$ recommended by Food and Agricultural Organization to be the minimum requirement for the growth and development of the body (Esobhawan et al., 2008). One way of increasing protein supply is to improve poultry production as well as increase the production of other small livestock species with short generation intervals. Among these is the Japanese quail (Coturnix Coturnix Japanica). Generally quail occupy a small but special segment of the Egyptian poultry industry. These birds are raised as source of specialty egg and meat. Japanese quail have the advantage of rapid growth rate, small size, good reproductive potential, short life cycle, low feed requirements, good meat taste, better laying ability and shorter time of hatching as compared with the different species of poultry (Roshdy et al., 2010 and Siyadati et al., 2011).

Vitamin $\mathrm{C}$, also called ascorbic acid, is presented as a natural antioxidant that can be used to reduce the oxidative stress imposed by heat stress. Supplementation of ascorbic acid at $250 \mathrm{mg} / \mathrm{kg}$ feed has been reported to improve feed intake, body weight gain and feed efficiency, and to enhance immune response and antioxidant status of broiler chickens (Khan et al., 2012). Abidin and Khatoon (2013) reported that vitamin $\mathrm{C}$ ameliorates production and immunity problems induced by heat stress such as suppressing immunity, lowering feed consumption, impairing body weight gain, inducing oxidative stress, increasing rectal temperature and increasing mortality in birds. 
Although poultry can synthesize vitamin C, synthesis is inadequate under stressful conditions such as low or high environmental temperature, high humidity, high egg production rate and parasite infestation (Sykes, 1978; McDowell, 1989). Such conditions, particularly in poultry, lead to generation of cytotoxic free radicals damaging the cells and cell membranes, increased protein catabolism, decreased protein biosynthesis and depletion of vitamin $\mathrm{C}$. Vitamin $\mathrm{C}$ and $\mathrm{E}$ supplementations are reported to be beneficial in alleviating some of the heat stress related physiological responses and improving thermotolerance through their antioxidant effects (Sahin and Kucuk, 2001; Sahin et al., 2006). Sahin et al. (2003) showed that dietary supplementation of vitamin C and E, particularly as a combination, improved the performance, and antioxidant status of laying Japanese quails exposed to heat stress. Chee et al. (2005) observed that vitamin $\mathrm{C}$ and vitamin $\mathrm{E}$ had got effect on egg shell quality of broiler breeder reared under heat stress conditions.

McKee et al. (1997) reported that ascorbic acid supplementation has the ability to influence body energy stores in favor of improving productivity when feed restriction lead to a reduction in the energy consumption of broilers.

Vitamin C with other vitamins such as vitamin E play a major role as antioxidants in biological systems and act individually or synergistically such that vitamin E explicates its antioxidant function in lipid phases whereas vitamin $\mathrm{C}$ in aqueous compartments by reacting with peroxyl radicals and by restoring the antioxidant properties of vitamin E (Cotelle et al., 2003). Studies on poultry have reported that dietary supplementation with vitamin C, alone can improve growth performance (Sahin and Kucuk 2001; Ajakaiye et al. 2010).

Al-Ghamdi (2008) suggested that the alteration in plasma vitamin C level can be used as a heat stress indicator in broiler chickens. He found a significant reduction in plasma ascorbic acid in broilers exposed to $40^{\circ} \mathrm{C}$ for three hours a day for ten days starting from day 22 of age. Sahin et al. (2009) recommended a combination of vitamins $\mathrm{C}$ and $\mathrm{E}$ supplementation $(500 \mathrm{mg}$ of each $1 \mathrm{~kg}$ of diet) to the diet of quail to improve egg production and heat shock protein synthesis during heat stress.

Therefore, the objective of the present study was to investigate the efficacy of overdosing of vitamin $\mathrm{C}$ supplementation as a good management practice in Japanese quail nutrition to promote growth performance, Europe production efficiency factor (EPEF),carcass criteria and some blood constituents of Japanese quail.

\section{MATERIALS AND METHODS}

The present study was carried out at the Poultry Research Farm of Department of Poultry Production in Assiut University. The objective of the present study was to investigate the efficacy of overdosing of vitamin $\mathrm{C}$ supplementation as be a good management practice in Japanese quail nutrition to promote growth performance, Europe production efficiency factor (EPEF), carcass criteria and some blood constituents of Japanese quail.

\section{Housing and experimental design:}

A total number of (two hundred and twenty five, one day old Japanese quail chicks were used in this experiment. The chicks were distributed into 5 treatments of 3 replicates (15 birds each).Experimental diets based on corn - soybean meal diets and contain $24 \%$ and $20 \%$ crude protein during starter and grower periods, respectively according to NRC 1994, recommendation. The ingredient composition and chemical analysis of the experimental diets used in the starting and growing period are presented in Table 1. Samples of the experimental diets were analyzed according to AOAC (1990). The experimental design was as follows:

Treatment 1: Chicks were fed basal diet without vitamin $\mathrm{C}$ supplementation (control).

Treatment 2: Chicks were fed basal diet supplemented with $65 \mathrm{mg}$ vitamin $\mathrm{C} / \mathrm{kg}$ feed.

Treatment 3: Chicks were fed basal diet supplemented with $130 \mathrm{mg}$ vitamin $\mathrm{C} / \mathrm{kg}$ feed.

Treatment 4: Chicks were fed basal diet supplemented with $260 \mathrm{mg}$ vitamin $\mathrm{C} / \mathrm{kg}$ feed. 
Treatment 5: Chicks were fed basal diet supplemented with $520 \mathrm{mg}$ vitamin $\mathrm{C} / \mathrm{kg}$ feed.

The experimental chicks were housed in galvanized batteries composed of three tiers, equipped with cages, having the dimensions of $(75 \mathrm{~cm}$ length, $50 \mathrm{~cm}$ width and $45 \mathrm{~cm}$ height $)$ and placed in a semi closed house. Chicks were raised under adequate and similar managerial, nutritional and hygienic conditions.

Table (1): Composition and analysis of the experimental basal diets.

\begin{tabular}{|c|c|c|}
\hline Ingredient & Starter \% & Grower, $\%$ \\
\hline Corn, Grains & 53.00 & 62.0 \\
\hline Soybean Meal (44\%) & 36.20 & 30.2 \\
\hline Vegetable oil & 1.00 & 1.0 \\
\hline Corn gluten Meal (60\%) & 6.40 & 3.4 \\
\hline Di calcium phosphate & 2.05 & 2.05 \\
\hline Vit . Min. Premix ${ }^{*}$ & 0.30 & 0.30 \\
\hline Limestone & 0.45 & 0.45 \\
\hline $\mathrm{NaCl}$ & 0.30 & 0.3 \\
\hline DL-Methionine & 0.15 & 0.15 \\
\hline L-Lysine $\mathrm{HCl}$ & 0.15 & 0.15 \\
\hline TOTAL & 100 & 100 \\
\hline \multicolumn{3}{|c|}{ Determined $^{l}$ and calculated ${ }^{2}$ composition } \\
\hline \multicolumn{3}{|c|}{ Nutrient_determined analysis } \\
\hline Dry matter & 85.82 & 87.8 \\
\hline Crude protein ${ }^{1}$ & 23.92 & 20.15 \\
\hline Ether extract ${ }^{1}$ & 3.51 & 3.2 \\
\hline Crude fiber ${ }^{1}$ & 4.02 & 4.0 \\
\hline \multicolumn{3}{|c|}{ Nutrient calculated analysis } \\
\hline Dry matter ${ }^{2}$ & 86.6 & 85.9 \\
\hline $\operatorname{ME}(\mathrm{kcal} / \mathrm{kg})^{2}$ & 2920 & 2857 \\
\hline Crude protein ${ }^{2}$ & 24.79 & 20.85 \\
\hline Ether extract ${ }^{2}$ & 3.46 & 3.5 \\
\hline Crude fiber $^{2}$ & 3.86 & 3.9 \\
\hline Calcium2 & 0.86 & 0.9 \\
\hline Available phosphorus ${ }^{2}$ & 0.53 & 0.47 \\
\hline Lysine $^{2}$ & 1.29 & 1.4 \\
\hline Methionine $^{2}$ & 0.59 & 0.51 \\
\hline Total phosphorus2 & 0.8 & 0.83 \\
\hline
\end{tabular}

*Vitamins and minerals mixture provide per kilogram of diet: Vitamin A (as all-trans-retinyl acetate); 12000 IU; Vitamin E (all rac- $\alpha$-tocopheryl acetate); $10 \mathrm{IU} ; k_{3} 3 \mathrm{mg}$; Vit. $D_{3}, 2200 \mathrm{ICU}$; riboflavin, $10 \mathrm{mg}$; Ca pantothenate, 10 $\mathrm{mg}$; niacin, $20 \mathrm{mg}$; Choline chloride, $500 \mathrm{mg}$; Vitamin $B_{12}, 10 \mu \mathrm{g}$; Vitamin $B_{6}, 1.5 \mathrm{mg}$; Thiamine (as thiamine mononitrate); $2.2 \mathrm{mg}$; Folic acid, $1 \mathrm{mg}$; D-biotin, 50 $\mathrm{g}$. Trace mineral (milligrams per kilogram of diet) Mn, 55; $\mathrm{Zn}$, 50; $\mathrm{Fe}, 30 ; \mathrm{Cu}, 10 ; \mathrm{Se}, 0.1$ and Ethoxyquin $3 \mathrm{mg}$.

Chicks were kept during the first three days of age to a lighting period of $23 \mathrm{hr} / \mathrm{day}$, which was gradually decreased by $1 \mathrm{hr} /$ day to reach $12 \mathrm{~L}: 12 \mathrm{D}$ hours/day during the rest of the growing period.

Body weight was recorded at one day old and each week per each replicate till 7 week.. Also, feed consumed was recorded each week till the last of the experiment. Body weight gain and feed conversion were calculated during the period from $0-7,0-14,0-21,0-28,0-35,0-42$ and $0-49$ days of age. Mortality was recorded daily. In the last of the experiment, three chicks from each replicate (total 45 chicks) were taken to slaughter to measure carcass parts, complete bleeding, scalding and plucking, the edible organs (heart, liver), breast, thigh, weighed and estimated as percentage of the live body weight. The dressing percentage was estimated by dividing the weight of the carcass giblets on the pre-slaughter body weight of birds.

Relative weight $=$ (organ weight/Live body weight $)$ X 100 . 


\section{Criteria studied:}

Body weight development, body weight gain and feed intake of quail birds in different treatments were weekly recorded. Body weight gain and feed conversion ratio (FCR) were calculated according to McDonald et al. (1987) and North (1981), respectively.

Depend on the calculations of FI, BWG, FCR and mortality, the European Production Efficiency Factor (EPEF) and European Broiler Index (EBI) were used to evaluate the growing performance of broilers as suggested by Marcu et al. (2013). EPEF and EBI were calculated according to the following formula:

TWG (Total weight gain) = Body weight $(\mathrm{g})$ at the end —Body weight $(\mathrm{g})$ at start;

ADG (Average daily gain, g/chick/day) $=$ TWG/ days of growth period.

FCR $(\mathrm{kg}$ feed $/ \mathrm{kg}$ gain $)=$ Cumulative feed intake $(\mathrm{kg}) /$ Total Weight gain $(\mathrm{kg})$;

Viability, $\%=100$ - mortality, $\%$

$\mathrm{EPEF}=$ Viability $(\%) \times \mathrm{BW}(\mathrm{kg}) * 100 /$ Age $(\mathrm{d}) \times \mathrm{FCR}(\mathrm{Feed} / \mathrm{kg}$ gain)

$\mathrm{EBI}=$ Viability $(\%) \times \mathrm{ADG}(\mathrm{g} /$ chick/day $) * 100 / \mathrm{FCR}(\mathrm{kg}$ feed/kg gain $) \times 10$

\section{Blood samples:}

At the end of the experimental period, blood samples were taken using 3 birds from each replicate. The blood samples were left to drop on the side of the tube to prevent destruction of RBC's. Each blood sample was left to coagulate at room temperature. Separation of serum was carried out by centrifugation of coagulated blood at $3000 \mathrm{rpm}$ for $10 \mathrm{~min}$. The clear serum was transferred carefully to clean and dry vials and kept in deep freezer until analysis for determination of serum glucose, total protein, calcium, phosphorus, total cholesterol and GPT using commercial kits obtained from Biodiagnostic Co.

\section{Statistical analysis:}

Data obtained were statistically analyzed by using ANOVA in one way experiment and General linear Model (GLM) procedure of SAS software (2009). Duncan's multiple range tests (1955), was used to determine the difference among means, Significant difference were considered to exist when $(\mathrm{P}<0.05)$.

The mathematical model used was:

$$
\mathrm{Y}_{\mathrm{i}}=\mu+\mathrm{Ti}+\mathrm{e}_{\mathrm{ik}}
$$

Where: $Y_{i K}$ is any abservation by vit $D 3, \mu=$ the population mean. $T_{i}=$ Treatment effect $(i=1,2, \ldots 5)$ $\mathrm{e}_{\mathrm{ik}}=$ Experimental random error.

\section{RESULTS AND DISCUSSION}

\section{Body Weight $(B W)$ :}

Results in (Table 2) showed that there were no significant $(\mathrm{P}>0.05)$ differences in body weight between treatments when compared to control at 7, 14, 28, 35 and 42 days of age .At 21 and 49 days of age, the highest body weight values were achieved in treatment 2, in which chicks were fed $130 \mathrm{mg}$ vitamin $\mathrm{C} / \mathrm{kg}$ feed. Body weight of chicks in such treatment was higher by about 12 and $8.8 \%$ than control. The obtained results were in agreement with Ramadan et al.,(2019) who reported that the best performance was observed in birds supplemented with $200 \mathrm{mg} / \mathrm{kg}$ vitamin C. Jain et al., (2019) mentioned that increased body weight, were observed in the supplemental groups as compared with control especially at higher levels of supplementation. The authors concluded that there was a beneficial effect of vitamin C supplementation in the diet of broilers on body weight, of broilers. Studies on poultry have reported that dietary supplementation with vitamins $\mathrm{C}$, alone, can improve growth performance (Sahin and Kucuk 2001; Ajakaiye et al. 2010) 
On the other hand, results of Ipek et al.( 2007) mentioned that the highest body weight was demonstrated in quail on $500 \mathrm{mg}$ of Vitamin C/kg feed and Durrani et al. (2008) found when giving Aloe extract $10 \mathrm{ml} /$ liter to broilers in drinking water resulted in better body weight.

Vathana et al. (2002) reported that during the first three weeks, no difference in body weight among different treatments was detected ( $>0.05$ ). However, a significant difference in body weight among groups was observed from the $3 \mathrm{rd}$ to the 6 th weeks. Birds in group received $40 \mathrm{mg} / \mathrm{bird} /$ day of vitamin $\mathrm{C}$ were the heaviest .The same results had been recorded by Edrise et al (1986). Similarly Lohakare et al. (2005) have also evaluated the efficacy of supplemental ascorbic acid on the performance of broiler chickens and reported significantly higher body weight in the supplemental groups at higher levels as compared with control. Rajput et al (2009) have also recorded increased live body weight in broiler birds supplemented with vitamin $\mathrm{C}$ at level of $500 \mathrm{mg} / \mathrm{kg}$ of feed in comparison to control birds. They added that the control registered significantly less mean body weight of broilers than the treatments, indicating thereby a significant beneficial effect of using vitamin $\mathrm{C}$ in the diet of broilers. The differences in the mean body weight of broilers among other treatments were non-significant, being at par. This indicates that all treatments irrespective of level of vitamin $\mathrm{C}$ in diet were more or less equally beneficial. Other researchers found that vitamin C supplementation at level of 150 or $300 \mathrm{mg} / \mathrm{kg}$ feed didn't achieve any significant ( $\mathrm{P}>0.05)$ effect on body weight (Knoca et al., 2009).

Table (2): Efficacy of overdosing of vitamin C supplementation on body weight of Japanese quail (g).

\begin{tabular}{|c|c|c|c|c|c|}
\hline \multirow[b]{2}{*}{ Period } & \multicolumn{5}{|c|}{ Treatment } \\
\hline & $\mathrm{T} 0$ & T 1 & T 2 & T 3 & $\mathrm{~T} 4$ \\
\hline 1 day old & $8.5 \pm 0.06$ & $9.2 \pm 0$ & $7.8 \pm 0.4$ & $8.4 \pm 0$ & $8.6 \pm 0$ \\
\hline 7 day & $20.9 \pm 0.9$ & $21.3 \pm 1.5$ & $19.5 \pm 0.56$ & $20.4 \pm 0.93$ & $21 \pm 0.86$ \\
\hline 14 day & $44 \pm 2.7$ & $44.8 \pm 0.9$ & $44.4 \pm 1.24$ & $43.2 \pm 1.61$ & $45.4 \pm 2.03$ \\
\hline 21 day & $68^{\mathrm{b}} \pm 1.39$ & $72.1^{\mathrm{ab}} \pm 2.75$ & $76.2^{\mathrm{a}} \pm 0.92$ & $68.7^{\mathrm{b}} \pm 1.7$ & $69.2^{\mathrm{b}} \pm 2.1$ \\
\hline 28 day & $120.2 \pm 1.6$ & $127.2 \pm 5$ & $124 \pm 4$ & $115 \pm 7$ & $127.2 \pm 4.3$ \\
\hline 35 day & $145.2 \pm 10$ & $149.3 \pm 2.4$ & $144.7 \pm 7.8$ & $134.3 \pm 7.9$ & $145.9 \pm 10.3$ \\
\hline 44 day & $158.3 \pm 10$ & $172.7 \pm 1.4$ & $163.3 \pm 6.7$ & $163.5 \pm 2.7$ & $176.7 \pm 9.8$ \\
\hline 49 day & $201.9^{\mathrm{b}} \pm 4.6$ & $214.4^{\mathrm{ab}} \pm 0.5$ & $219.7^{\mathrm{a}} \pm 6.5$ & $200.7^{\mathrm{b}} \pm 3.8$ & $216.6^{\mathrm{ab}} \pm 7.5$ \\
\hline
\end{tabular}

\section{Body weight gain:}

Results in (Table 3) indicate that no significant $(\mathrm{P}>0.05)$ in body weight gain were obtained between treatment when compared to control during the periods from 0-7, 0-14, 0-28, 0-35 and 0-42 days of age .However, during the periods from 0- 21 and 0-49 days of age, the results showed showed that the highest body weight gain values were achieved in treatment 2 , in which chicks were fed $130 \mathrm{mg}$ vitamin $\mathrm{C} / \mathrm{kg}$ feed. Body weight gain of chicks in treatment 2 was higher than control treatment by about 14.9 and $9.56 \%$, respectively. The obtained results were in agreement with Jain et al., (2019) who mentioned that increased, body weight gain were observed in the supplemental groups as compared with control especially at higher levels of supplementation. The authors concluded that there was a beneficial effect of vitamin C supplementation in broilers diets on body weight gain. Supplementation of ascorbic acid at $250 \mathrm{mg} / \mathrm{kg}$ feed has been reported to improve body weight gain and to enhance immune response and antioxidant status of broiler chickens (Khan et al., 2012).

In particular, vitamin $\mathrm{C}$ promotes performance associated with the suppressed-stress responses as indicated by lowering the plasma corticosterone level and adrenocorticotropic hormone (Lin et al. 2006; Ahmadu et al. 2016). Nevertheless, it has been suggested that vitamin C effectiveness on poultry performance expresses only in environmental stress condition whereas, it is not detectable under normal temperature condition (Newman and Leeson 1999; Saki et al. 2010).The higher body weight gains have been reported by Mans and Larbier (1986) by supplementation of diet with vitamin C with lower stocking density. Ipek et al. (2007) reported that the highest body weight gain was demonstrated in quail on $500 \mathrm{mg}$ of Vitamin $\mathrm{C} / \mathrm{kg}$ feed. 
Table (3): Efficacy of overdosing of vitamin C supplementation on body weight gain of Japanese quail (g).

\begin{tabular}{llllll}
\hline & \multicolumn{5}{c}{ Treatment } \\
\cline { 2 - 6 } Period & \multicolumn{1}{c}{ T0 } & \multicolumn{1}{c}{ T 1} & \multicolumn{1}{c}{ T 2} & T 3 & T 4 \\
\hline 0-7 day & $12.4 \pm 0.87$ & $12.1 \pm 1.5$ & $11.7 \pm 0.94$ & $12.02 \pm 0.9$ & $12.7 \pm 0.86$ \\
0 -14 day & $35.5 \pm 2.7$ & $35.6 \pm 0.91$ & $36.6 \pm 1.2$ & $34.8 \pm 1.6$ & $36.8 \pm 2.03$ \\
0-21 day & $59.5^{\mathrm{b}} \pm 1.3$ & $62.9^{\mathrm{ab}} \pm 2.8$ & $68.4^{\mathrm{a}} \pm 1.3$ & $60.3^{\mathrm{b}} \pm 1.7$ & $60.6^{\mathrm{b}} \pm 2.1$ \\
0-28 day & $111.7 \pm 1.9$ & $118 \pm 4.9$ & $116.2 \pm 3.1$ & $106.6 \pm 6.9$ & $118.6 \pm 4.3$ \\
0-35 day & $136.7 \pm 10.4$ & $140.1 \pm 2.4$ & $136.9 \pm 7.4$ & $125.9 \pm 7.9$ & $137.3 \pm 10.3$ \\
0-44 day & $149.8 \pm 10.1$ & $163.5 \pm 1.4$ & $155.5 \pm 5.3$ & $155.1 \pm 2.7$ & $168.2 \pm 9.8$ \\
0-49 day & $193.4^{\mathrm{b}} \pm 4.5$ & $205.2^{\mathrm{ab}} \pm 0.6$ & $211.9^{\mathrm{a}} \pm 6.2$ & $192.3^{\mathrm{b}} \pm 3.8$ & $208^{\mathrm{ab}} \pm 7.5$ \\
\hline
\end{tabular}

$a, b$, means in the same rows with different superscripts are significantly different $p<0.05)$. T0 $=$ control diet, $T 1=(65$ mg of Vit. C/kg feed $), T 2=(130 \mathrm{mg}$ of Vit. C/kg feed $), T 3=(260 \mathrm{mg}$ of Vitt. C/kg feed $), T 4=(520 \mathrm{mg}$ of Vit.. C/kg feed $)$.

On the other hand, Tuleun et al., (2011) found that there were no significant differences in mean daily weight gain, between treatments and the control group (vitamin $\mathrm{C}$ free diet). Vitamin $\mathrm{C}$ supplementation at level of 150 or $300 \mathrm{mg} / \mathrm{kg}$ feed didn't achieve any significant $(\mathrm{P}>0.05)$ effect on body weight gain (Knoca et al., 2009).

\section{Feed consumption (FC):}

Results in (Table 4) showed that, there are no significant $(\mathrm{P}>0.05)$ in feed consumption between treatment when compared to control during the periods from 0-7, 0-14, 0-35, 0-42 and 0-49 days of age .However, during the periods from 0- 21 and 0-28 days of age, the results showed significant differences as that the highest feed consumed values were achieved in chicks were fed $520 \mathrm{mg}$ vitamin $\mathrm{C} / \mathrm{kg}$ feed. Feed consumed in treatment 4 in which chicks were fed $520 \mathrm{mg} / \mathrm{kg}$ feed was higher than control by about 5.65 and $4.76 \%$, respectively. The obtained results were in agreement with Jain et al., (2019) who mentioned that increased feed intake were observed in vitamin $\mathrm{C}$ supplemental groups as compared with control especially at higher levels of supplementation. This indicate the beneficial effect of vitamin $\mathrm{C}$ supplementation in the diet of broilers on feed intake of broilers. Supplementation of ascorbic acid at 250 $\mathrm{mg} / \mathrm{kg}$ feed has been reported to improve body weight gain and to enhance immune response and antioxidant status of broiler chickens (Khan et al., 2012). Ipek et al. (2007) reported that the highest feed intake was demonstrated in quail on $500 \mathrm{mg}$ of Vitamin $\mathrm{C} / \mathrm{kg}$ feed.

Table (4): Efficacy of overdosing of vitamin C supplementation on feed consumption of Japanese quail at different periods $(\mathrm{g})$.

\begin{tabular}{lccccl}
\hline & \multicolumn{5}{c}{ Treatment } \\
\cline { 2 - 6 } Period & T0 & T 1 & T 2 & T 3 & T 4 \\
\hline 0-7 day & $22.2 \pm 0$ & $22.2 \pm 0$ & $22.2 \pm 0$ & $22.2 \pm 0$ & $22.2 \pm 0$ \\
0 -14 day & $104.7 \pm 1.2$ & $104 \pm 1.2$ & $105.3 \pm 1.8$ & $103.1 \pm 2.02$ & $104.7 \pm 1.7$ \\
0-21 day & $153.9^{\mathrm{ab}} \pm 27$ & $149.2^{\mathrm{b}} \pm 2$ & $151.1^{\mathrm{b}} \pm 1.1$ & $158.2^{\mathrm{ab}} \pm 2.9$ & $162.6^{\mathrm{a}} \pm 4$ \\
0-28 day & $273.1^{\mathrm{ab}} \pm 2$. & $268.5^{\mathrm{b}} \pm 4.7$ & $274.9^{\mathrm{ab}} \pm 3.3$ & $276.9^{\mathrm{ab}} \pm 5.4$ & $286.1^{\mathrm{a}} \pm 6$ \\
0-35 day & $436.8 \pm 2.1$ & $431.8 \pm 5.4$ & $441.7 \pm 7.1$ & $443.6 \pm 7.7$ & $453.6 \pm 10$ \\
0-44 day & $633.2 \pm 2.2$ & $637.9 \pm 4.5$ & $642.2 \pm 12$ & $653.8 \pm 7.9$ & $655 \pm 14.9$ \\
0-49 day & $830.8 \pm 2.3$ & $845.6 \pm 7.4$ & $845.1 \pm 16.8$ & $870.9 \pm 2.7$ & $857.4 \pm 20$ \\
\hline
\end{tabular}

$a, b$, means in the same rows with different superscripts are significantly different $p<0.05) . T 0=$ control diet, $T 1=(65$ $\mathrm{mg}$ of Vit. C/kg feed $), T 2=(130 \mathrm{mg}$ of Vit. C/kg feed $), T 3=(260 \mathrm{mg}$ of Vitt. C/kg feed $), T 4=(520 \mathrm{mg}$ of Vit.. C/kg feed $)$.

\section{Feed conversion ratio $(\mathrm{FCR})$ :}

Results in (Table 5) showed that, there are no significant $(\mathrm{P}>0.05)$ effect on feed conversion ratio between treatment when compared to control during the periods from 0-7, 0-14, 0-35 and 0-42 days of 
age .However, during the periods from 0-21, 0-28 and 0-49 days of age, the results showed the presence of significant difference that, the best feed conversion ratio values were achieved in chicks fed $130 \mathrm{mg}$ vitamin $\mathrm{C} / \mathrm{kg}$ feed and was better by 9-3\% than control treatment. The obtained results confirmed those of Khan et al., (2012) who stated FCR can be improved by supplementation of ascorbic acid at 250 $\mathrm{mg} / \mathrm{kg}$ feed and to enhance immune response and antioxidant status of broiler chickens. .Ipek et al. (2007) reported that the best feed conversion ratio was demonstrated in quail on $500 \mathrm{mg}$ of Vitamin C/kg feed.

On the other hand, The obtained results are in disagreement with Jain et al., (2019) who concluded that vitamin C is not essential for improvement of FCR or the performance of broilers. However, Tuleun et al., (2011) found that there were no significant differences in mean feed conversion ratio, between treatments and the control group (AA free diet)

Ascorbic acid can be considered as one of the most potent naturally occurring antioxidants because it works by reacting with aqueous peroxyl radicals and by restoring the antioxidant properties of vitamin $\mathrm{E}$ (Cotella et al., 2003). AA has been suggested to act synergistically with tocopherol to regenerate the tocopheryl radicals. AA may scavenge peroxyl radical and inhibit cytotoxicity induced by oxidants. In addition, AA can reduce or prevent $\mathrm{H} 2 \mathrm{O} 2$-induced lipid peroxidation and the formation of $\mathrm{OH}$ deoxyguanosine (Yena et al., 2002). Such effect of vitamin C can be reflected positively on growth and feed utilization.

Table (5): Efficacy of overdosing of vitamin $\mathrm{C}$ supplementation on feed conversion ratio of Japanese quail ( $\mathrm{g}$ feed/g gain).

\begin{tabular}{|c|c|c|c|c|c|}
\hline \multirow[b]{2}{*}{ Period } & \multicolumn{5}{|c|}{ Treatment } \\
\hline & T0 & $\mathrm{T} 1$ & T 2 & T 3 & T 4 \\
\hline $0-7$ & $1.8 \pm 0.1$ & $1.9 \pm 0.23$ & $1.9 \pm 0.17$ & $1.9 \pm 0.15$ & $1.8 \pm 0.12$ \\
\hline $0-14$ & $2.9 \pm 0.19$ & $2.9 \pm 0.11$ & $2.9 \pm 0.14$ & $2.9 \pm 0.1$ & $2.9 \pm 0.19$ \\
\hline $0-21$ & $2.6^{\mathrm{ab}} \pm .04$ & $2.4^{\mathrm{bc}} \pm 0.14$ & $2.2^{c} \pm 0.05$ & $2.6^{\mathrm{ab}} \pm 0.1$ & $2.7^{\mathrm{a}} \pm 0.03$ \\
\hline $0-28$ & $2.4^{\mathrm{ab}} \pm 0.01$ & $2.3^{\mathrm{b}} \pm 0.12$ & $2.4^{\mathrm{ab}} \pm 0.1$ & $2.6^{\mathrm{a}} \pm 0.13$ & $2.4^{\mathrm{ab}} \pm 0.03$ \\
\hline $0-35$ & $3.2 \pm 0.21$ & $3.1 \pm 0.1$ & $3.3 \pm 0.22$ & $3.5 \pm 0.17$ & $3.3 \pm 0.17$ \\
\hline $0-42$ & $4.3 \pm 0.26$ & $3.9 \pm 0.03$ & $4.1 \pm 0.18$ & $4.2 \pm 0.11$ & $3.9 \pm 0.13$ \\
\hline $0-49$ & $4.3^{\mathrm{ab}} \pm 0.11$ & $4.12^{\mathrm{b}} \pm 0.03$ & $3.9^{\mathrm{b}} \pm 0.18$ & $4.5^{\mathrm{a}} \pm 0.07$ & $4.13^{\mathrm{b}} \pm 0.12$ \\
\hline
\end{tabular}

\section{European production efficiency factor (EPEF) and European broiler index (EBI).}

Date presented in Table (6), showed the Europe Production efficiency Factor (EPEF) and Europe Broiler Index (EPI) values of Japanese quail during the period from one day old to 49 days of age. The results of EPEF and EPI showed that the overdose of vitamin C supplementation didn't achieve the highest performance values of EPEF and EPI (10.7) and (1026.6) compared to the other doses of vitamin $\mathrm{C}$ and control chicks, respectively. However, the highest values of both EPEF and EPI were achieved by chicks fed $130 \mathrm{mg} / \mathrm{kg}$ of vitamin C. The values were 11.49 and 1107.6 , respectively compared with the control.

If for instance a very low density is used during the grow-out period, the daily gain and with it the EBI will most likely go up, but the profit per square meter will go down, and the last one is economically of more interest.

If a low density, cheap feed is used, the daily growth and feed conversion might be negatively influenced, and with it the EBI, but the net profit per kg of meat might go up.

\section{Carcass criteria:}

The results of carcass traits as affected by vitamin C levels are presented in (Table 7).The results showed that there were no $(\mathrm{P}>0.05)$ significant differences due to vitamin $\mathrm{C}$ overdose on carcass weight, dressed $\%$, blood weight, blood $\%$, breast weight, breast $\%$, thigh weight, thigh $\%$, heart weight, heart $\%$, liver weight and liver\%. The obtained results are in agreement with that reported by Konca et al., (2009) who found that dietary vitamin C supplementation did not improve carcass parts and edible 
Table (6): Effect of treatments on European Production Efficiency Factor and European Broiler Index of Japanese quail.

\begin{tabular}{ccccccccccc}
\hline $\mathrm{T}$ & $\mathrm{R}$ & Bw0 & $\begin{array}{c}\text { BW- } \\
\text { 49day(g) }\end{array}$ & $\begin{array}{c}\text { BW- } \\
\text { (9day(kg) }\end{array}$ & T WG & ADG & FCR & $\begin{array}{c}\text { Viability, } \\
\%\end{array}$ & EPEF & EBI \\
\hline 0 & 1 & 8.5 & $201.9^{\mathrm{b}}$ & 0.2019 & 193.4 & 3.95 & $4.3^{\mathrm{ab}}$ & 100 & 9.58 & $918.6^{\mathrm{b}}$ \\
1 & 1 & 9.2 & $214.4^{\mathrm{ab}}$ & 0.2144 & 205.2 & 4.18 & $4.12^{\mathrm{b}}$ & 100 & 10.62 & $1014.5^{\mathrm{a}}$ \\
2 & 1 & 7.8 & $219.7^{\mathrm{a}}$ & 0.2197 & 211.9 & 4.32 & $3.9^{\mathrm{b}}$ & 100 & 11.49 & $1107.6^{\mathrm{a}}$ \\
3 & 1 & 8.4 & $200.7^{\mathrm{b}}$ & 0.2007 & 192.3 & 3.92 & $4.5^{\mathrm{a}}$ & 100 & 9.10 & $871.1^{\mathrm{b}}$ \\
4 & 1 & 8.6 & $216.6^{\mathrm{ab}}$ & 0.2166 & 208 & 4.24 & $4.13^{\mathrm{b}}$ & 100 & 10.70 & $1026.6^{\mathrm{a}}$ \\
\hline
\end{tabular}

EPEF = Europe Production efficiency Factor. $\quad$ EBI= Europe Broiler Index.

$B w 0=$ Body weight at one day old. TWG (Total weight gain, $g$ ). ADG=average daily gain during 49 days of age. Viability=100-\%mortality

Table (7): Efficacy of different dietary levels of vitamin $\mathrm{C}$ on carcass traits.

\begin{tabular}{lccccc}
\hline & \multicolumn{4}{c}{ Treatment } \\
\cline { 2 - 5 } Item & T0 & T 1 & T 2 & T 3 & T 4 \\
\hline Live_BW,g & $241.7 \pm 6.7$ & $241.7 \pm 9.8$ & $251.7 \pm 7.3$ & $246.1 \pm 2$ & $252.8 \pm 8.2$ \\
After bleed,g & $235 \pm 6.6$ & $234.4 \pm 9.3$ & $245 \pm 7.3$ & $238.3 \pm 2.5$ & $245.6 \pm 7.7$ \\
BloodW,g & $6.7 \pm 0.7$ & $7.2 \pm 0.6$ & $6.7 \pm 3.3$ & $7.8 \pm 0.6$ & $7.2 \pm 0.6$ \\
CarcassW,g & $179.4 \pm 5.5$ & $175 \pm 5.4$ & $184.4 \pm 2$ & $173.3 \pm 3.5$ & $177.2 \pm 7.7$ \\
carcass,\% & $74.3 \pm 1.9$ & $72.5 \pm 0.7$ & $73.4 \pm 1.8$ & $70.4 \pm 0.8$ & $70.1 \pm 0.8$ \\
blood,\% & $2.8 \pm 0.4$ & $2.9 \pm 0.2$ & $2.7 \pm 0.1$ & $3.2 \pm 0.2$ & $2.9 \pm 0.1$ \\
BreastW,g & $94.25 \pm 2.6$ & $94.3 \pm 3.8$ & $98.2 \pm 2.8$ & $95.9 \pm 0.8$ & $98.6 \pm 3.2$ \\
Breast_\% & $39 \pm 2.9$ & $39 \pm 2.9$ & $39 \pm 2.9$ & $39 \pm 0$ & $39 \pm 4.1$ \\
ThighW,g & $58 \pm 1.6$ & $58 \pm 2.3$ & $60.4 \pm 1.7$ & $59.1 \pm 0.5$ & $60.7 \pm 1.9$ \\
Thigh_,\% & $24 \pm 1.5$ & $24 \pm 0$ & $24 \pm 2.1$ & $24 \pm 0$ & $24 \pm 0$ \\
HeartW,g & $2.4 \pm 0.1$ & $2.4 \pm 0.1$ & $2.5 \pm 0.1$ & $2.5 \pm 0.02$ & $2.5 \pm 0.1$ \\
Heart,\%_- & $1 \pm 4.5$ & $1 \pm 0$ & $1 \pm 4.5$ & $1 \pm 0$ & $1 \pm 4.5$ \\
LiverW,g & $7.3 \pm 0.2$ & $7.3 \pm 0.3$ & $7.6 \pm 0.2$ & $7.4 \pm 0.1$ & $7.6 \pm 0.2$ \\
Liver_,\% & $3 \pm 1.8$ & $3 \pm 0$ & $3 \pm 2.6$ & $3 \pm 0$ & $3 \pm 0$ \\
\hline a,b, means in the same rows with different superscripts are significantly different $p<0.05)$. T0= control diet, Tl= $(65$
\end{tabular}

organs and abdominal fat yields. The current results are in agreement with Fletcher and Cason (1991) and Celik and Ozturkcan (2003), who found that ascorbic acid supplementation have no effect on carcass and abdominal fat. However, some studies suggested that dietary ascorbic acid supplementation increased carcass (Kutlu, 2001; Sahin et al., 2003; Lohakare et al., 2005), breast (Lohakare et al., 2005), liver, heart, spleen and empty gizzard weight (Sahin et al., 2003) and decreased abdominal fat pad (Kutlu, 2001; Sahin et al., 2003).

\section{Blood serum constituents:}

The results of blood parameters biochemical constituents as affected by overdosing of vitamin C supplementation are presented in (Table 8). There were no significant $(\mathrm{P}>0.05)$ differences due to vitamin $\mathrm{C}$ levels on the measured blood serum parameters. Some of the obtained results agree with several author such as Clegg et al. (1976) a nd McKee et al. (1997) who reported that dietary vitamin C supplementation did not affect blood cholesterol and plasma triglyceride (McKee et al., 1997) in broilers and albumin, creatine and glucose (Seyrek et al., 2004) in quails. On the contrary these findings the reduction of blood cholesterol (Kutlu and Forbes, 1993; Sahin et al., 2003), triglyceride (Clegg et al., 1976) and glucose (Kutlu and Forbes, 1993; Sahin et al., 2003) concentrations by feeding ASA have been demonstrated in broilers and quails (Gursu et al., 2004; Sahin et al., 2002). 
Egyptian J. Nutriqtion and Feeds (2021)

Table (8): Efficacy of overdosing of vitamin C supplementation on blood serum constituents of Japanese quail.

\begin{tabular}{lccccc}
\hline & \multicolumn{5}{c}{ Treatments } \\
\cline { 2 - 6 } Item & T0 & T 1 & T 2 & T 3 & T 4 \\
\hline SGOT (AST) $(\mathrm{U} / \mathrm{ml})$ & $21.1^{\mathrm{ab}} \pm 1.3$ & $18.9^{\mathrm{b}} \pm 0.8$ & $41.6^{\mathrm{a}} \pm 2.3$ & $26.8^{\mathrm{ab}} \pm 3.3$ & $19.3^{\mathrm{b}} \pm 1.3$ \\
SGPT (ALT)(U/ml) & $14.5^{\mathrm{b}} \pm 4$ & $17.1^{\mathrm{b}} \pm 2.4$ & $20.4^{\mathrm{a}} \pm 1.3$ & $16.9^{\mathrm{b}} \pm 1.1$ & $15.0^{\mathrm{b}} \pm 1.3$ \\
Total Protein (g/dl) & $6.6^{\mathrm{a}} \pm 0.2$ & $1.3^{\mathrm{ab}} \pm 0.4$ & $3.6^{\mathrm{b}} \pm 0.1$ & $2.5^{\mathrm{a}} \pm 0.2$ & $3.2^{\mathrm{b}} \pm 0.3$ \\
Cholesterol (mg/dl) & $199.0^{\mathrm{b}} \pm 4.5$ & $175.4^{\mathrm{b}} \pm 7.3$ & $347.8^{\mathrm{a}} \pm 9.3$ & $77.5^{\mathrm{c}} \pm 4.3$ & $121.6^{\mathrm{b}} \pm 6.2$ \\
Glucose (mg/dl) & $326.0 \pm 7.3$ & $478.3 \pm 9.3$ & $412.8 \pm 11$ & $372.3 \pm 8$ & $422.7 \pm 13$ \\
T. Calcium, \% & $11.5 \pm 0.3$ & $13.5 \pm 0.6$ & $10.7 \pm 0.4$ & $11.8 \pm 0.2$ & $10.7 \pm 0.3$ \\
T.Phosphorus, \% & $6.2^{\mathrm{a}} \pm 0.2$ & $6.2^{\mathrm{a}} \pm 0.3$ & $4.3^{\mathrm{b}} \pm 0.4$ & $6.1^{\mathrm{a}} \pm 0.2$ & $6.5^{\mathrm{a}} \pm 0.3$ \\
\hline
\end{tabular}

$a, b$, means in the same rows with different superscripts are significantly different $p<0.05)$.

$T 0=$ control diet $, T 1=(65 \mathrm{mg}$ of Vit. $\mathrm{C} / \mathrm{kg}$ feed $), T 2=(130 \mathrm{mg}$ of Vit. $\mathrm{C} / \mathrm{kg}$ feed $), T 3=(260 \mathrm{mg}$ of Vitt. $\mathrm{C} / \mathrm{kg}$ feed),T4=(520 mg of Vit.. C/kg feed).

Also, sahin et al. (2003) reported that dietary ASA supplementation increased serum protein in broilers. In the current study, dietary vitamin $\mathrm{C}$ supplementation caused a quadratic change in the AST and a linear and quadratic decrease in the serum ALT levels $(\mathrm{p}<0.05)$. The ALT catalyzes the transfer of an amino group from alanine to $\alpha$-ketoglutarate, the products of this reversible transamination reaction being pyruvate and glutamate. It is used as a liver function test and elevated levels monitored liver malfunction (Murray et al., 1990). On the contrary to those results, Sahin et al. (2002) and Gursu et al. (2004) reported that dietary ASA did not affect serum ALT and AST levels in quails.

Current findings showed that feeding vitamin C at supra-nutritional levels can't be a good management practice in Japanese quail nutrition to promote growth performance traits under thermoneutral environmental conditions.

It has been suggested that vitamin $\mathrm{C}$ effectiveness on poultry performance expresses only in environmental stress condition whereas is not detectable under normal temperature conditions (Newman and Leeson 1999; Saki et al.2010).Oxidative lesions, leading to conformational modifications of proteins, could induce pancreatic enzyme inhibition and/or dietary protein resistance to digestion (Ahmadu et al.2016). Consequently, antioxidants, such as vitamin $\mathrm{E}$ and/or C, could contribute in preserving the proteins from oxidative denaturation improving digestibility of nutrients and their metabolic utilisation (Panda et al. 2008; Ahmadu et al. 2016). As already observed in previous study (Sigolo et al. 2018), under thermoneutral condition, vitamin C added at high doses $(520 \mathrm{mg} / \mathrm{kg})$ to quail diet seem to help in promoting a general animals' welfare which results in raised growth. Vitamin $\mathrm{C}$ is required forthe proper development and function ofmany parts of the body. It also plays an important role in maintaining proper immune function. Vitamin C supplementation to non-stressed broilers at the first 21 days of life positively modulate the production performance.

Elagib-Hind and Omer (2012) reported that BW was improved by the low and moderate levels (150 and $350 \mathrm{mg} / \mathrm{kg}$ ) of V.C compared with the higher level. Also, SabahElkheir et al. (2008) observed that V.C supplementation at higher doses $(500 \mathrm{mg}$ and $750 \mathrm{mg} / \mathrm{kg}$ ) resulted in lower final weight and weight gain. Previous studies reported that V.C supplementation increased body gain (Sahin andKucuk, 2001). On the other hand, others found that broiler feed intake was not affected by the V.C supplementation (Blaha and Kroesna, 1997; Jaffar and Blaha, 1996).

In general, results obtained suggested that additional vitamin $\mathrm{C}$ in quail diets had some beneficial effect on some of examined parameters such as crude fat of meat, colour of thigh in broiler chicks, but most of parameters did not influenced by the dietary vitamin C supplementation. However, there were a number of fundamental differences among reports, including the basal diets, genetic stocks used and environmental conditions of the experiments. Further experiments should need to be conducted to determine whether the effect of vitamin $\mathrm{C}$ at different conditions in quail.

In conclusion, although vitamin $\mathrm{C}$ added to quail diet recorded better findings compared to control, however, the overdose level of vitamin $\mathrm{C}$ are recommended particularly under stressful conditions. 


\section{REFERENCES}

Abidin, Z. and A. Khatoon (2013). Heat stress in poultry and the beneficial effects of ascorbic acid (vitamin C) supplementation during periods of heat stress. World's Poultry Science Journal, 69 (1): 135-152.

Ahmadu S., A. A. Mohammed, H. Buhari and A. Auwal (2016). An overview of vitamin C as an antistress in poultry. Malays J Vet Res. 7:9-22.

Ajakaiye, J.J, A. Perez-Bello, M Cuesta Mazorra, G. PolancExpósito and Á. Mollineda Trujillo (2010). Vitamins C and E affect plasma metabolities and production performance of layer chickens (Gallus gallusdomesticus) under condition of high ambient temperature and humidity. Arch. Anim. Breed. 53:708-719.

Al-Ghamdi, H. 2008. Effects of Commutative Heat Stress on Immunoresponses in Broiler Chickens Reared in Closed System. International Journal of Poultry Science 7(10)

AOAC (1990). Association of Official Analytical Chemists.Official.Methods of Analysis (13th Ed) Washington, D.C., U.S.A.

Blaha J.., and K Kroesna (1997). Effect of vitamin and electrolytes supplements on broiler performance, slaughter value and chemical composition of meat during the heat stress. UniversitäsAgriculturäePraga Press 1997; 30: 103-13. 24

Celik, L. and O. Ozturkcan, (2003). Effects of dietary supplemental L-carnitine and ascorbic acid on performance, carcass composition and plasma L-carnitine concentration of broiler chicks reared under different temperature. Arch. Anim. Nutr., 57: 27-38.

Chee, K. M., M. K. Chung, J. H. Choi and Y. K. Chung (2005). Effects of Dietary Vitamins C and E on Egg Shell Quality of Broiler Breeder Hens Exposed to Heat Stress.Asian-Aust. J. Anim. Sci. 18(4):545-551.

Clegg, R.E., C.F. Klopfenstein and W.E. Klopfenstein (1976) . Effect of diethylstilbestrol, ascorbic acid and vitamin E on serum lipid patterns.Poult. Sci., 55: 1104-1111.

Cotelle P, N. Cotelle, E. Teissier and H. Vezin (2003). Synthesis and antioxidant properties of a new lipophilic ascorbic acid analogue. Bioorganic Med Chem. 11:1087-1093.

Duncan's, D.B. (1955). .Multiple Range And Multiple F Tests. Biometrics,11:1-42.

Edrise, B. M., A. W. Khair-El-din, and R. Soliman (1986). The immuno potentiating effect of ascorbic acid against Newcastle disease in chicken. Vet. Med. J. 34 (2): 251- 264.

Elagib-Hind A.A. and H.M. Omer (2012).Effect of Dietary Ascorbic Acid on Performance and Immune Response of Heat Stressed Broiler Chicks. Pakistan J Nutr 2012; 11(3): 216-20.

Esobhawan, A. O., S. O. Ojo and E. E Ikhelao (2008). Profitability, input elasticity and returns to scale in agriculture production in Lagos State. Proceedings of $14^{\text {th }}$ Annual Conference of Agriculture In Nigeria. Wetlands FUTA, Akure.219-222.

Fletcher, D.L. and J.A. Cason (1991). Influence of ascorbic acid on broiler shrink and processing yields. Poult. Sci., 70: 2191-2196

Gaurav, J. Neeraj and R. Pandey (2018). Effect of Vitamin C on Growth Performance of Caged Broilers.Adv.Biores.,Vol 9 (2) March 2018: 178-181.

Gursu, M.F., M. Onderci, F. Gulcu and K. Sahin (2004). Effects of vitamin C and folic acid supplementation on serum paraoxonase activity and metabolites induced by heat stress in vivo.Nutr. Res., 24: 157-164.

Ipek, A., O. Canbolat and A. Karabulut (2007). Effect of vitamin E and Vitamin C supplementation as a combination on performance of Japanese quails (Coturnixcoturnix japonica) reared under heat stress during the growth and egg production period. Asian-Aust. J. Anim. Sci. 20:(2) : $252-256$.

Jaffar G.H. and J. Blaha (1996). Effect of ascorbic acid supplementation in drinking water on growth rate, feed consumption and feed efficiency of broiler chickens maintained under acute heat stress conditions. Universitas AgriculturaePraga Press 1996; 41: 485-90. 
Jain, S.K; , .M.Y. Dar, S. Kumar, A. Yadav and S.R. Kearns (2019). Role of anti-oxidant (vitamin-C) in post-operative pain relief in foot and ankle trauma surgery: A prospective randomized trial. Epub 2018 May 24.

Khan, R. U.; S. Naz; Z. Nikousefat; M. Selvaggi; V. Laudadio and V. Tufarelli (2012). Effect of ascorbic acid in heat-stressed poultry. World's Poultry Science Journal, 68(3): 477-490.

Konca,Y., F. Kirkpinar, S. Mert and S. Yurtseven (2009). Effects of dietary ascorbic acid supplementation on growth performance, carcass, bone quality and blood parameters in broilers during natural summer temperature. asian journal of animal and veterinary advances, 4: 139-147.

Kutlu, H.R. and J.M. Forbes (1993). Changes in growth and blood parameters in heat-stressed broiler chicks in response to dietary ascorbic acid.LivestockProd. Sci., 36: 335-350.

Kutlu, H.R (2001). Influences of wet feeding and supplementation with ascorbic acid on performance and carcass composition of broiler chicks exposed to a high ambient temperature. Arch. Tierernahrung, 54: 127-139.

Lin H, H.C. Jiao, J. Buyse, E. Decuypere (2006). Strategies for preventing heat stress in poultry. Worlds PoultSci J. 62: 71-86.

Lohakare, J. D., M. H. Ryu, T.W. Hahn, J. K. Lee and B. J. Chae (2005). Effects of Supplemental Ascorbic Acid on the Performance and Immunity of Commercial Broilers. J. Appl. Poult. Res. $14: 10-19$.

Mans, F. and M. Larbier (1986). Effect of vitamin C in broiler flocks Seventh European conference, Pairs, volume 1. General genetics, nutrition, posters, undated, 353-357.

Marcu, A., Vacaru- I., Gabi, D., Liliana, P.C., Marcu, A., Marioara, N., Ioan, P., Dorel, D., Bartolomeu, K. and M. Cosmin, 2013.The Influence of genetics on economic efficiency of broiler chickens growth. Anim. Sci. Biotech. 46, 339346.

McDonald, P., R. A. Edwards and J. F. D. Greenhelgh (1987). Animal Nutrition text .English Language BookSocity/Longman

McDowell, L. R.(1989). Vitamins in animal nutrition: Vitamin C, folacin. In: Comparative Aspects to Human Nutrition. (Ed. L. R. McDowell), Academic Press, London, UK. pp. 298-322.

McKee, J. S.; P. C. Harrison and G. L. Riskowski (1997). Effects of supplemental ascorbic acid on the energy conversion of broiler chicks during heat stress and feed withdrawal. Poultry Science, 76(9): 1278- 1286.

Newman S, and S. Leeson (1999). The effect of dietary supplementation with 1,25dihydroxycholecalciferol or vitamin $\mathrm{C}$ on the characteristics of the tibia of older laying hens. Poult Sci. 78:85-90.

North, M. O. (1981). Commercial Longman chicken production, 3rdEd.AVI.Publishingcompany INC, USA.

NRC (1994) National Research Council, Nutrient Requirements of Poultry. $9^{\text {th }}$ Rev. Edn. National Academy Press, Washington, DC

Omoikhoje, S. O., A. M. Bamgbose, and M. B Aruna (2008). Replacement value of unpeeled cassava root meal (UCRM) for maize in weaner Rabbit Diets. Nig. J. Anim. Prod. 35: 63-68.

Panda AK, S.V Ramarao, MVLN Raju and R.N. Chatterjee (2008). Effect of dietary supplementation with vitamins $\mathrm{E}$ and $\mathrm{C}$ on production performance, immune responses and antioxidant status of White Leghorn layers under tropical summer conditions. Br Poult Sci. 49:592-599.

Rajput ,A.B., B.R. Kolte, J.M. Shisodiya, J.M. Chandankhede and J.M. Chahande (2009). Effect of Viatmin A, Vitamin C, Vitamin E and Levamisole on Performance of Broilers Veterinary World, Vol.2 (6): 225-227.

Ramadan S Shewita, Karima El-Naggar, Walaa S. Abd El Naby (2019). Influence of dietary vitamin c supplementation on growth performance, blood biochemical parameters and transcript levels of heat shock proteins in high stocking density reared broiler chickens. Vol 56, Suppl 22

Roshdy, M., Khalili, H. A., Hanafy, M., and M. E. Mady, 2010. Egypt poult. Sci. 30 (I): 55-67. 
Sabah Elkheir M.K., A.M.M., Mohammed and A S. M. bdel-Gadir (2008). Effect of Feed Restriction and Ascorbic Acid Supplementation on Performance of Broiler Chicks Reared under Heat Stress. Res J Ani \& Vet Sci; 3: 1-8.

Sahin K and O. Kucuk (2001). Effects of vitamin C and E on performance, digestion of nutrients and carcass characteristics of Japanese quails reared under chronic heat stress $\left(34^{\circ} \mathrm{C}\right)$. $\mathrm{J}$ Anim.Physiol.Anim.Nutr. 85:335-341.

Sahin N., K. Sahin, M. Onderci, M. Karatepe, M.O. Smith, and O..Kucuk (2006). Effects of dietary lycopene and vitamin $\mathrm{E}$ on egg production, antioxidant status and cholesterol levels in Japanese quail.Asian-Australas. J Anim Sci. 19:224-230.

Sahin, K., N. Sahin and S. Yaralioglu (2002). Effects of vitamin c and vitamin e on lipid peroxidation, blood serum metabolites and mineral concentrations of laying hens reared at high ambient temperature. Biol. Trace Elem. Res., 85: 35-45.

Sahin, K., N. Sahin, and O. Kucuk (2003). Effects of chromium and ascorbic acid supplementation on growth carcass traits serum metabolites and antioxidant status of broiler chickens reared at a high ambient temperature $\left(32^{\circ} \mathrm{C}\right)$. Nutr. Res., $23,225-238$.

Sahin, N.; M. Tuzcu; C. Orhan; M. Onderci; Y. Eroksuz and K. Sahin (2009). The effects of vitamin C and $\mathrm{E}$ supplementation on heat shock protein 70 response of ovary and brain in heat-stressed quail. British Poultry Science, 50(2): 259-265.

Saki A.A., M.M.H. Rahmati, P. Zamani, K. Zaboli and H.R.H Matin. (2010). Can vitamin C elevate laying hen performance, egg and plasma characteristics under normal environmental temperature? Ital J Anim Sci. 9:317.

SAS.(2009). User's Guide. Version, 9.2, 2002-2009, SAS institute Inc., Cary, NC.

Sigolo S., R. Khazaei, A. Seidavi, T. Ayasan, A. Gallo and A. Prandini (2018). Effects of supranutritional levels of vitamin $\mathrm{E}$ and vitamin $\mathrm{C}$ on growth performance and blood parameters of Japanese quails.Ital J Anim Sci.

Siyadati, S., M. Irani, , K. Ghazvinian, , A. Mirzaei-Aghsaghali, , V. Rez, aipoor, , H. Fathi, , K. Alipoor, , and S. Zamanzad-Ghavidel (2011). Effect of varying dietary energy to Protein ratio on productive performance and carcass Characteristics of Japanese quail.Annals. Biol. Res. 2 (1): 149-155.

Sykes, A. H. (1978). Vitamin C for poultry: some recent research. In: Proceedings of the Roche Symposium. pp. 5-15, 1978.

Tuleun C. D., A.Y. Adenkola and T. Afele (2011). Effect of dietary ascorbic acid supplementation on the performance of Japanese (Coturnixcoturnix japonica) quails in a tropical envi, ronment.Journal of Animal \& Plant Sciences, 2011. Vol. 10, Issue 2: 1268- 1275.

Vathana S, K. Kang, C. Loan, G. Thinggaard, J.D. Kabasa and U. Meulen (2002). Effect of vitamin C supplementation on performance of broiler chickens in cambodia. Proceedings of the Conference on International Agricultural Research for Development Witzenhausen; 2002 Oct 9-11; Witzenhausen. Germany: Deutscher Tropentag;

Yena, G.C., P.D. Duhb and H.L. Tsaia (2002): Antioxidant and pro-oxidant properties of ascorbic acid and andgallic acid. Food Chemistry. 79, 307-313. 
تأثير الجرعات العالية من اضافة فيتامين C علي معدل اداء النمو ومعامل كفاعة الانتاج الاوربى وصفات الذبيحة وبعض مكونات الام في السمان الياباني

مصطفى محمد متولى 1و محمد متولى احمد²

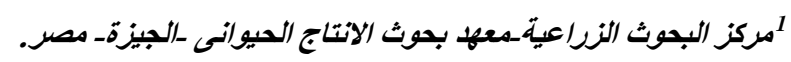

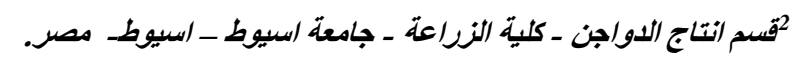

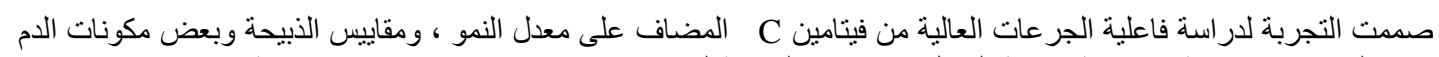

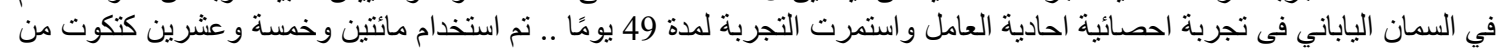

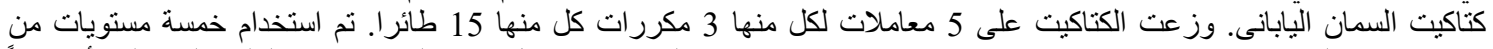

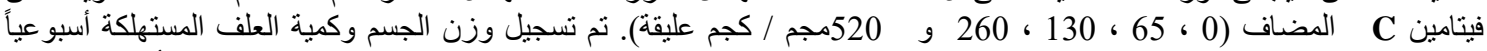

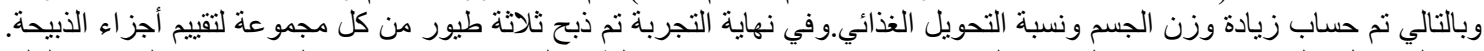

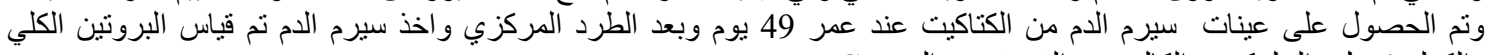

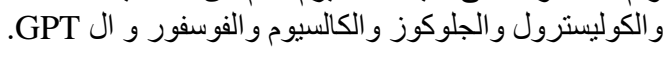

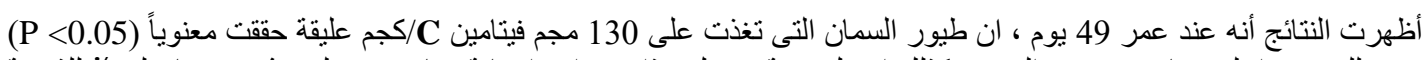

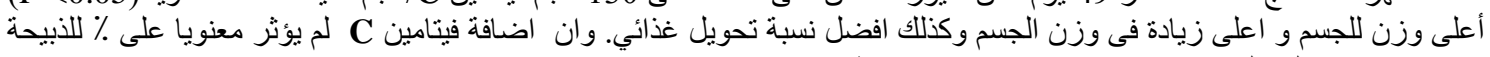

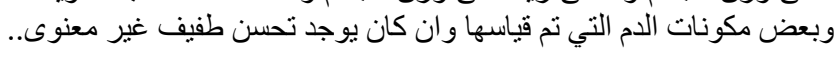

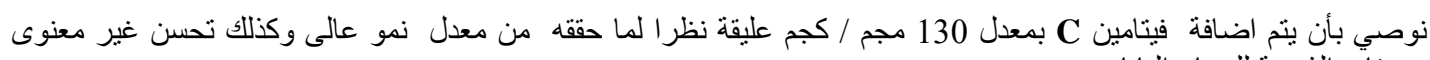
لبعض صفات الذبيحة للسمان الياباني. 